\title{
The Effect of the COVID-19 Pandemic on Insomnia: Incidence, Characteristics, Therapy and Prevention
}

\author{
Danny Shan Veda ${ }^{1 *}$, Venny Pungus ${ }^{2}$, Daniel C.A. Nugroho ${ }^{1}$, Efrayim Suryadi ${ }^{3}$
}

\author{
${ }^{1}$ Medical Faculty, Duta Wacana Christian University, Yogyakarta, Indonesia \\ ${ }^{2}$ Psychiatry Department, Bethesda Hospital, Yogyakarta, Indonesia \\ ${ }^{3}$ Medical Faculty, Gadjah Mada University, Yogyakarta, Indonesia
}

DOI: $10.36347 /$ sjams.2022.v10i01.017

| Received: 13.12.2021 | Accepted: 17.01.2022 | Published: 22.01.2022

*Corresponding author: Danny Shan Veda

Medical Faculty, Duta Wacana Christian University, Yogyakarta, Indonesia

\section{Abstract}

The COVID-19, which has been stated as pandemic since March 2020 by the World Health Organization (WHO), has affected various aspects of life globally. Apart from having a significant impact on the health sector, its inception has also affected other sectors, with people losing their jobs, increasing unemployment and poverty rates, and lifestyle changes. However, not everyone is ready to face an uncertain situation due to its impact on mental health, leading to insomnia. During the pandemic, most insomnia incidents increased with various risk factors, which are usually preceded by symptoms of anxiety in response to stressors. Subsequently, the signs and symptoms of insomnia include difficulty sleeping and waking up early. Therefore, this study determined the effect of the Covid-19 pandemic on insomnia, its prevalence, therapy, and prevention efforts. The result showed that insomnia therapy developed during the pandemic is Cognitive Behavior Therapy and breathing technique exercises. This therapy should be conducted optimally to minimize risk factors and prevent worsening symptoms.

Keywords: COVID-19, Insomnia, Cognitive Behaviour Therapy.

Copyright $\odot 2022$ The Author(s): This is an open-access article distributed under the terms of the Creative Commons Attribution 4.0 International License (CC BY-NC 4.0) which permits unrestricted use, distribution, and reproduction in any medium for non-commercial use provided the original author and source are credited.

\section{INTRODUCTION}

Insomnia is difficulty initiating or maintaining sleep continuity. Insomnia belongs to the group of sleep disorders in DSM-V. In order to function properly, adults need at least 7 hours of sleep [1-3].

The COVID-19 pandemic has impacted various sectors of human life, especially the health sector, which has adversely affected the economy. On February 27, 2021, WHO reported a total of $112,902,746$ confirmed cases and 2,508,679 deaths due to the virus. A total of 50,246,580 positive cases were reported in America, 38,361,386 in Europe, 13,492,895 in Southeast Asia, 6,360,314 in Eastern Mediterranean, 2,827,228 in Africa, and 1,613,598 in Western Pacific.
Meanwhile on January 5, 2022, WHO reported a total of 293,750,692 confirmed cases and 5,454,131 deaths due to the virus [4-5].

The number of positive confirmed cases has led to many changes in societal activities and excessive anxiety. Incidence of the pandemic in the community worsened the symptoms of insomnia in patients. This pandemic also affects sleep quality which in turn leads to acute insomnia in some people and worsens symptoms of the disease in the populations already experiencing this health defect. Therefore, this study describes the impact of the pandemic on mental health, especially insomnia, through a comprehensive literature review [6-7]. 
Danny Shan Veda et al; Sch J App Med Sci, Jan, 2022; 10(1): 101-110

Tabel-1: The incidence of insomnia during the COVID-19 pandemic

\begin{tabular}{|c|c|c|c|}
\hline NO. & Authors & Group & Result \\
\hline 1. & Zhan et al, 2020 & $\begin{array}{l}\text { 1,794 front-line nurses in Wuhan, } \\
\text { China }\end{array}$ & $52.8 \%$ experienced insomnia \\
\hline 2. & $\begin{array}{l}\text { Martin et al, } \\
\quad 2020\end{array}$ & $\begin{array}{c}100 \text { health workers and } 70 \text { non-health } \\
\text { workers in Madrid, Spain }\end{array}$ & $\begin{array}{c}\text { Insomnia was more common in the health } \\
\text { care group }\end{array}$ \\
\hline 3. & $\begin{array}{c}\text { Brito-Marques et } \\
\text { al, } 2021\end{array}$ & 332 doctors in Brazil & $\begin{array}{l}65.6 \% \text { experienced changes in sleep } \\
\text { patterns }\end{array}$ \\
\hline 4. & $\begin{array}{l}\text { Hanggoro et al., } \\
2020\end{array}$ & $\begin{array}{l}\text { Health workers conducted in } \\
\text { Pontianak City, Indonesia }\end{array}$ & $47.9 \%$ experienced insomnia \\
\hline 5. & $\begin{array}{l}\text { Bhargava et al, } \\
2020\end{array}$ & $\begin{array}{l}594 \text { dermatologists in various } \\
\text { countries }\end{array}$ & 182 experienced insomnia \\
\hline 6. & Wang et al, 2020 & $\begin{array}{c}\text { COVID-19 patients at Wuhan Tongji } \\
\text { Hospital }\end{array}$ & $42.8 \%$ patients experienced insomnia \\
\hline 7. & Wang et al, 2021 & $\begin{array}{c}\text { Case-controlled study in China } \\
\text { involved 1,674 participants } \\
\text { quarantined for } 2 \text { weeks and 1,743 } \\
\text { controls }\end{array}$ & $\begin{array}{c}\text { Quarantined population had higher scores } \\
\text { on the Patient Health Questionnaire-9 } \\
\text { (PHQ-9) and ISI than the general } \\
\text { population }\end{array}$ \\
\hline 8. & Wang et al, 2021 & $\begin{array}{c}460 \text { COVID-19 patients in Hubei, } \\
\text { China }\end{array}$ & 171 experienced insomnia \\
\hline 9. & $\begin{array}{l}\text { Zhang et al, } \\
\qquad 2020\end{array}$ & $\begin{array}{c}\text { 2,027 Chinese citizens living in } \\
\text { Wuhan }\end{array}$ & $\begin{array}{c}59.7 \% \text { of the participants did not have good } \\
\text { sleep quality, and } 50.9 \% \text { had varying short } \\
\text { sleep duration problems }\end{array}$ \\
\hline 10. & Liu et al, 2021 & 2,992 respondents in China & $19.6 \%$ experienced insomnia \\
\hline 11. & $\begin{array}{l}\text { Mongkhon et al, } \\
2021\end{array}$ & Citizens in Thailand & $\begin{array}{c}\text { Population that exposed to the information } \\
\text { for } 3 \text { hours or more has a greater risk of } \\
\text { experiencing insomnia }\end{array}$ \\
\hline 12. & Bajaj et al, 2020 & 391 respondents in India & ISI result of $8.59 \pm 5.79$ \\
\hline 13. & $\begin{array}{l}\text { Radhakrishnan } \\
\text { et al, } 2021\end{array}$ & 450 respondents in India & $33.3 \%$ experienced severe dyssomnia \\
\hline 14. & $\begin{array}{l}\text { Alfitri \& } \\
\text { Widiatrilupi, } \\
2020\end{array}$ & $\begin{array}{l}\text { Adolescent respondents in Tanjung } \\
\text { Rejo and Kasin Villages, Malang City, } \\
\text { Indonesia }\end{array}$ & $44.4 \%$ experienced insomnia \\
\hline 15. & $\begin{array}{l}\text { Firmansyah et } \\
\text { al, } 2020\end{array}$ & Citizens in Jakarta, Indonesia & 110 experienced insomnia \\
\hline 16. & $\begin{array}{c}\text { Tobing \& } \\
\text { Wulandari, } 2021\end{array}$ & $\begin{array}{c}\text { Elderly people with comorbid diseases } \\
\text { in Parongpong Sub-District, West } \\
\text { Bandung Regency, Indonesia }\end{array}$ & Anxiety symtomps followed by insomnia \\
\hline 17. & $\begin{array}{l}\text { Fauziyah \& } \\
\text { Aretha, } 2021\end{array}$ & $\begin{array}{l}81 \text { Medical Faculty Students at } \\
\text { Muhammadiyah University Surakarta, } \\
\text { Indonesia }\end{array}$ & $48.1 \%$ had poor sleep quality \\
\hline 18. & Zreik et al, 2020 & Mothers and children in Israel & Increase in insomnia from $11 \%$ to $23 \%$ \\
\hline 19. & $\begin{array}{l}\text { Al-Ajlouni et al } \\
2020\end{array}$ & 1,240 respondents in Jordan & $60 \%$ experienced sleep problem \\
\hline 20. & $\begin{array}{l}\text { Hetkamp et al, } \\
2020\end{array}$ & German population of 16,245 people & $13.5 \%$ experienced sleep disturbances \\
\hline
\end{tabular}


Danny Shan Veda et al; Sch J App Med Sci, Jan, 2022; 10(1): 101-110

\begin{tabular}{|c|c|c|c|}
\hline NO. & Authors & Group & Result \\
\hline 21 & $\begin{array}{l}\text { Chouchou et al, } \\
2021\end{array}$ & $\begin{array}{c}400 \text { volunteers of Reunion Island in } \\
\text { France }\end{array}$ & $\begin{array}{l}15.7 \% \text { decrease in well-being followed by } \\
\text { poorer sleep quality }\end{array}$ \\
\hline 22. & Philip et al, 2020 & French community & 773 people had ISI score more than 14 \\
\hline 23. & $\begin{array}{l}\text { Duran \& Erkin, } \\
2021\end{array}$ & 405 Turkish & $55.1 \%$ experienced poor sleep quality \\
\hline 24. & Bect et al, 2021 & Study in France & $\begin{array}{c}\text { Sleep problems decreased during last weeks } \\
\text { of lockdown }\end{array}$ \\
\hline 25. & Sun et al, 2021 & People with mental disorders & $\begin{array}{l}\text { insomnia increased significantly from } \\
57.8 \% \text { to } 66.0 \%\end{array}$ \\
\hline 26. & Zou et al, 2020 & $\begin{array}{l}\text { Old psychiatric patients in several } \\
\text { hospitals in China }\end{array}$ & Insomnia associated with fatigue \\
\hline 27. & Li et al, 2021 & $\begin{array}{l}\text { Elderly patients with psychiatric } \\
\text { disorders }\end{array}$ & $56.9 \%$ had ISI score of 8 \\
\hline 28. & $\begin{array}{l}\text { Ubara et al, } \\
\qquad 2020\end{array}$ & $\begin{array}{l}164 \text { patients that visited the outpatient } \\
\text { clinic at Shiga University Hospital }\end{array}$ & $\begin{array}{l}\text { Increased sleep duration and poor AIS } \\
\text { scores are associated with worsening } \\
\text { depressive symptoms }\end{array}$ \\
\hline 29. & Xia et al, 2020 & 119 Parkinson's patients in China & $68.9 \%$ had sleep disturbances \\
\hline 30. & $\begin{array}{l}\text { Kitani-Morii et } \\
\quad a l, 2021\end{array}$ & Parkinson's patients in Japan & Increase in insomnia cases \\
\hline 31. & $\begin{array}{l}\text { Necho et al, } \\
2020\end{array}$ & People with disabilities in Ethiopia & $71 \%$ experienced insomnia \\
\hline 32. & $\begin{array}{l}\text { Cox \& Olatunji, } \\
2021\end{array}$ & Subset of the American population & $\begin{array}{l}\text { Small decrease in insomnia symptoms from } \\
2016 \text { until the beginning of the pandemic }\end{array}$ \\
\hline
\end{tabular}

\section{The incidence of insomnia in the Health Workers group during the COVID-19 pandemic}

One group that feels the impact of the pandemic on changes in sleep quality is health workers consisting of doctors, nurses, and other personnel in hospitals. In a study of 1,794 front-line nurses from four general tertiary hospitals in Wuhan, China, the prevalence of insomnia was 52.8\% [8]. Another study in Madrid, Spain, involving the completion of questionnaires by 170 participants consisting of 100 health workers and 70 non-health workers, showed that insomnia was more common in the health care group. Its prevalence is $57 \%$, with $29 \%$ of the respondents having problems with starting to sleep, $24 \%$ finding it difficult to maintain the regular sleep pattern, and $30 \%$ waking up early. When compared with the general population of non-health workers, the prevalence of insomnia is $24.39 \%$, with $22.86 \%$ having problems starting to sleep, $12.86 \%$ finding it difficult to maintain its pattern, and $11.43 \%$ waking up early. This indicates that front-line healthcare workers experience more sleep disturbances with poorer quality than non-health professionals [9].

A study in Brazil using 332 doctors showed that $65.6 \%$ experienced changes in sleep patterns.
Furthermore, by measuring the prevalence of insomnia using the Insomnia Severity Index (ISI), 37.2\%, 23.3\%, and $5.1 \%$ were in the mild, moderate, and severe categories [10]. In Indonesia, a survey of health workers conducted in Pontianak City showed that $47.9 \%$ experienced insomnia. The perception of those at risk of being exposed to the virus is significantly related to psychological problems, such as anxiety disorders, depression, and insomnia [11]. In another study on dermatologists group using data from a website-based survey in various countries, 182 of 594 (30\%) respondents experienced insomnia [12].

\section{The incidence of insomnia in COVID-19 patients and the quarantine population}

A total of $484(99.0 \%)$ of the 489 hospitalized COVID-19 patients at Wuhan Tongji Hospital were used as respondents that met all participation criteria and completed the assessment. The results showed that the prevalence of insomnia disorders in these 484 patients was $42.8 \%$ [13]. Subsequently, a casecontrolled study conducted at the Department of Psychiatry of the Shenzhen Longgang Chronic Disease Control Center in Shenzhen, China, involved 1,674 participants between 18 to 65 years, quarantined for 2 weeks and 1,743 controls. The result showed that the 
Danny Shan Veda et al; Sch J App Med Sci, Jan, 2022; 10(1): 101-110

quarantined population had higher scores on the Patient Health Questionnaire-9 (PHQ-9) and ISI than the general population [14]. A study in Hubei, China, also implied insomnia problems experienced by 171 out of $460(42.01 \%)$ COVID-19 patients [15].

\section{The incidence of insomnia in the general population during the COVID-19 pandemic}

Numerous preliminary studies were also conducted on the general population, apart from the health workers. For instance, a study conducted on 2,027 Chinese citizens living in Wuhan indicated that $59.7 \%$ of the participants did not have good sleep quality, and $50.9 \%$ had varying short sleep duration problems. Furthermore, a total of $44.1 \%$ and $33.0 \%$ had sleep disturbances and difficulty sleeping [16]. Another previous study conducted in China showed that of the 2,992 respondents, $19.6 \%$ experienced insomnia [17]. Subsequently, a study conducted in Thailand examined the relationship between the duration of exposure to information on COVID-19 and insomnia. The results indicated that the population exposed to the information for 3 hours or more has a greater risk of experiencing insomnia than exposure for 1 hour [18].

In the early phase of the pandemic, another survey conducted in India using 391 respondents from various sociodemographic characteristics showed an ISI result of $8.59 \pm 5.79$ [19]. A study conducted in an Indian population of 450 respondents proved that $33.3 \%$ of people with severe dyssomnia exhibit high daytime sleep disturbances, negative emotionality, and high susceptibility to the COVID-19 pandemic measures. Meanwhile, people with moderate dyssomnia (28.5\%) presented frequent awakenings with sleep disturbances during the day, and the majority $(38.2 \%)$ were not affected by the pandemic [20].

In Indonesia, almost half of female and male adolescent respondents in Tanjung Rejo and Kasin Villages, Malang City, experience insomnia due to internet use with a total of 105 adolescents or $44.4 \%$ [21]. Incidence of insomnia in Jakarta during the LargeScale Social Restrictions (PSBB) due to the COVID-19 pandemic and found that 110 out of 281 respondents or $39.1 \%$ were affected [22]. A study in a group of elderly people with comorbid diseases, such as heart, hypertension, and diabetes mellitus in Parongpong SubDistrict, West Bandung Regency, using 66 respondents, showed that the symptoms of anxiety during the pandemic were the highest feelings of anxiety, depression, fear, tension, insomnia and behavior [23]. A study on 81 Medical Faculty Students at Muhammadiyah University Surakarta, and the result revealed that $48.1 \%$ had poor sleep quality [24].

Studies on mothers and children in Israel during the pandemic revealed that there is an increase in insomnia from $11 \%$ to $23 \%$ [25]. In a population of 1,240 in Jordan, $60 \%$ experienced at least one sleep problem in the past week, and nearly half had a short sleep duration [26]. Furthermore, the study in a German population of 16,245 people showed that $13.5 \%$ of the web survey participants experienced sleep disturbances during the early phase of the pandemic [27]. A study to evaluate the impact of the lockdown in Reunion Island in France using 400 volunteers revealed a $15.7 \%$ decrease in well-being and weekly physical activity and increased anxiety, delays, and poorer sleep quality [28]. The French community also conducted a study to determine the visibility of the application as a virtual agent for sleep disturbance interventions. Participants who took part in the intervention were 773 people identified as having sleep disorders based on an ISI score of more than 14 [29]. A study of 405 Turkish showed that participants' average psychological distress and sleep quantity scores are $34.55 \pm 8.07$ and $6.39 \pm$ 3.31. The prevalence of poor sleep quality is $55.1 \%$ [30]. According to a study conducted in France, sleep problems decreased significantly during the last weeks of the lockdown [31].

\section{The incidence of insomnia in other populations}

Apart from the COVID-19 patients, those with mental disorders are also prone to experiencing insomnia. In the population with mental disorders, insomnia increased significantly from $57.8 \%$ to $66.0 \%$ and $24.8 \%$ to $31.5 \%$ in the control population compared to before the pandemic [32]. Fatigue in old psychiatric patients in several hospitals in China were significantly associated with insomnia [33]. A multicenter study in China on clinically stable elderly patients with psychiatric disorders showed the prevalence of insomnia based on the ISI with a total score of 8 or $56.9 \%[34]$.

In a population in Shiga, Japan, a study was also conducted to compare the sleep habits and mental health of 164 patients that visited the outpatient clinic at Shiga University Hospital of Medical Sciences before and after the pandemic using the Athens Insomnia Scale (AIS) questionnaire. The results implied that patients that experienced self-isolation insignificantly changed their sleeping habits. However, attention needs to be paid to those that experience increased sleep duration and poor AIS scores because they are associated with worsening depressive symptoms. This disease is more significant in self-isolating patients [35].

A study of 119 Parkinson's patients in China indicated that $68.9 \%$ had sleep disturbances [36]. Meanwhile, a study on Parkinson's patients in Japan also showed an increase in insomnia [37]. Other vulnerable groups that experience this problem are people with disabilities. As many as $71 \%$ of 280 people with disabilities in Ethiopia experience insomnia with varied severity of $232(57.6 \%), 48(11.9 \%)$, and 6 $(1.1 \%)$ participants in the sub-threshold, moderate, and severe categories, respectively [38]. However, this is contrary to the study of a subset of the American 
Danny Shan Veda et al; Sch J App Med Sci, Jan, 2022; 10(1): 101-110

population, which indicated a small decrease in insomnia symptoms from 2016 until the beginning of the pandemic [39].

\section{Characteristics of Insomnia Incidence in COVID-19 Patients and Populations Under Quarantine \\ Studies on the incidence of insomnia in} COVID-19 patients generally have a relationship with quarantine conditions. Wang et al. (2020) stated that those likely to develop insomnia in China are female gender, younger age, and people with higher fatigue and anxiety levels [13].

Another study in China using data from a quarantined population suggested a significantly higher risk of depression, anxiety, and insomnia in positive patients when compared to the general population [14]. The study of 460 COVID-19 patients in Hubei had 187 $(40.65 \%)$ health workers and $297(64.57 \%)$ women. The most common psychological problems were somatoform disorders $(66.09 \%, \mathrm{n}=304)$, depression $(53.48 \%, \mathrm{n}=246)$, anxiety $(46.30 \%, \mathrm{n}=213)$, insomnia $(42.01 \%, \mathrm{n}=171)$, and thoughts of self-harm or suicide (23.26\%, $\mathrm{n}=107)$. The incidence of insomnia tends to be more often found in the female respondents that experienced divorce, loss, symptoms of fever, health workers that received oxygen inhalation therapy, and respondents in need of psychological counseling [15].

\section{Characteristics of Insomnia Incidence in Health Workers during the COVID-19 Pandemic}

The discussion regarding the characteristics of insomnia on health workers during the pandemic is generally associated with the intensity of work. Studies on front-line nurses in China revealed that gender, work experience, chronic illness, duration of naps, direct participation in rescuing COVID-19 patients, frequency of night shifts, professional psychological assistance during the pandemic, negative experiences, level of fear, fatigue, and perceived stress are factors that influence the incidence of insomnia [8].

A case-controlled study in Madrid, Spain, examined the factors that influence insomnia among medical workers, namely age above or equal to 35 and shift workers, while in the non-health worker group, it is the female gender [9]. A study involving doctors in Brazil reported that almost half $(47.4 \%)$ of the respondents' doctors had comorbidities. Mental health disorders (13.3\%) such as depression, generalized anxiety, panic, and bipolar were the most commonly reported comorbidities. This symptom is considered relevant because psychiatric conditions contribute to sleep disturbances. More than $25 \%$ of psychiatric patients have similar symptoms with post-traumatic stress and moderate to severe insomnia [10].

Studies conducted on dermatologists from various countries showed that mental stress was significantly related to the length of experience as a doctor, the number of patients seen per week before the pandemic, availability of personal protective equipment (PPE) in hospitals, and location (continental). Furthermore, dermatologists practicing in North America $(83.9 \%)$ and Asia $(81.4 \%)$ experienced more mental distress than those in Central/South America $(68.7 \%)$ and Europe $(65.3 \%)$. Mental health disorders are also associated with inadequate facilities for practicing doctors during the pandemic. Stress is associated with hospital care and depression with being overwhelmed by the amount of information received on the pandemic [12]. Hanggoro et al. (2020) stated that health workers in Pontianak city, Indonesia, responsible for COVID-19 patients are more at risk of experiencing problems such as insomnia [11].

\section{Characteristics of Insomnia Incidence in the General Population during the COVID-19 Pandemic}

Discussion on the incidence of insomnia in the general population has many relationships with the sociodemographic conditions of each respondent. A study conducted in India in the early phase of the pandemic involving 408 respondents suggested that women, the young (age 19-29 years), low-income earners (INR < 40,000), and population with high anxiety levels are at risk of experiencing insomnia, compared to men, the old (age > 41 years), high-income earners (INR 40,000), and populations with high anxiety [19].

Studies involving mothers and children in Israel denoted a correlation between maternal insomnia, children's sleep variables, and acute maternal anxiety on COVID-19. Mother ISI scores were positively correlated with children's sleep latency, the number of the night wakes, negatively correlated with sleep duration. The mother's acute anxiety is positively correlated with the number of children's nightly wakes and their sleep duration. Subsequently, the correlation between the mother's current ISI score and the children's sleep variable with acute maternal anxiety as a covariate and the number of night awakenings remained significant [25].

A study conducted in China examining the relationship history of contact with an outbreak area in Wuhan revealed that sleep quality, difficulty in getting it, disturbances, and duration were all associated with symptoms of post-traumatic stress. Respondents with poor sleep quality were influenced by a history of contact with outbreak areas, while those with good quality exhibited symptoms of post-traumatic stress [16]. Another study in China related to insomnia showed that gender was a significant factor while age was insignificant. People suffering from chronic diseases are more prone to have high insomnia symptoms [17].

Beck et al. (2021) stated that sleep problems decreased significantly at the end of the lockdown in 
Danny Shan Veda et al; Sch J App Med Sci, Jan, 2022; 10(1): 101-110

France, and this trend was confirmed one month after with higher prevalence in women and young people [31]. A study conducted using the Thai population, exposure to information on COVID-19 for more than 3 hours per day increases the risk of insomnia [18].

A study of Turkish society proved psychological distress scores were higher among men than women, married respondents, children, and working professionals. The quality of sleep in single people with low levels of education is worse than married people. Furthermore, the quality of sleep in those that lost their jobs during the pandemic was worse than those working from home and those that had not worked before. The sleep quality of respondents that do not work in the health sector is better than health workers [30].

Studies conducted in Indonesia established that internet users with a duration of more than 7 hours impact adolescent development, such as insomnia [21]. Fauziyah and Aretha (2021) stated that medical students in Solo that experience anxiety, depression, and stress risk getting poor sleep quality [24]. The elderly population in Parongpong Sub-District, West Bandung, exhibit severe anxiety and insomnia symptoms, which respondents more often experienced with comorbid heart disease, hypertension, and diabetes mellitus. According to Tobing \& Wulandari (2021), elderly women with comorbidities have more severe anxiety than men [23].

\section{Characteristics of Insomnia Incidence in Other Populations during the COVID-19 Pandemic}

Studies on insomnia incidence in other special populations include people with mental disorders, Parkinson's, and disabilities. In China, patients with mental disorders infer an increasing incidence of insomnia. According to Sun et al. (2021), patients that previously experienced mental disorders have worsened symptoms of mental health symptoms, such as depression and anxiety [32]. Another previous study revealed that the incidence of insomnia is associated with fatigue in patients with mental disorders, which is related to those living in rural areas. This is because they have limited access to psychiatric services, which worsened the illness during a pandemic, leading to comorbid major depressive disorder and a low level of education [33].

Studies on patients with Parkinson's in Wuhan implied that sleep disturbances had a statistically significant association with postural instability and gait disturbances, symptom exacerbations, anxiety, depression, and inadequate medical consultation. Evaluation of risk factors for sleep disturbances demonstrated exacerbation of symptoms and anxiety were independently associated with sleep disturbances in Parkinson's patients. Meanwhile, women tend to present higher PSQI scores, poorer sleep quality, shorter sleep duration, and more severe daytime sleepiness. Furthermore, they were more prone to anxiety and depression, during the pandemic, with a greater ability to follow the news regarding the virus [36]. Studies on populations with disabilities exhibit significantly higher insomnia in single, divorced, widowed, separated, unemployed, blind, deaf, and leprosy victims compared to other disability groups [38].

American studies of different states showed varying insomnia symptoms from 2016 to after the pandemic. This decrease is related to the factors of residence and condition of the house as well as the type of work. Minor improvements in sleep during the pandemic were experienced by groups of workers that benefited from reduced punctuality demands and increased schedule flexibility. Most of the groups involved in this study are professionals that can work from home with access to many resources. This supports improving sleep quality during the pandemic [39].

Insomnia Therapy during the COVID-19 Pandemic

The treatment of insomnia is generally divided into pharmacological and non-pharmacological therapies. Cognitive Behavior Therapy (CBT) is a nonpharmacological therapy commonly used to improve sleep quality. This therapy is carried out based on the individual symptoms experienced by the patient. In handling insomnia, the main goal of therapy is to improve sleep patterns and quality. This process is generally carried out with health professionals in the form of psychoeducation. The development of an online CBT method through the "My Health too" CBT program is key to increasing stress resistance and preventing mental health problems [40]. The program consists of 7 video sessions of approximately 20 minutes with the following components:

1. Psychological mechanisms of stress. This session discusses psychoeducation in Lazarus and Folkman's transactional stress model, cognitive restructuring techniques to understand harmful thoughts and seek alternatives to deal with thoughts that trigger anxiety.

2. Useful behavior when stressed. This session discusses functional coping strategies, such as problem-solving, social support, relaxation, and deepening cognitive restructuring.

3. Mindfulness in daily life. This session discusses mindfulness, observes emotions as objects, encourages mindfulness exercise for 3 minutes, and helps participants learn to let go.

4. Increase awareness with a focus on "today and now" to increase mental resilience. This session discusses the acceptance skills of the conditions experienced.

5. Take meaningful action. This session discusses understanding values related to emotions, value identification, and worthy actions. 
Danny Shan Veda et al; Sch J App Med Sci, Jan, 2022; 10(1): 101-110

6. Self-compassion to improve self-care. In this session, psychoeducation was given on compassion as a psychological skill to calm emotions, barriers to self-pity, and affection as a means of self-care.

7. Self-compassion to improve emotion regulation skills. This session discusses the use of selfcompassion to calm difficult emotions and as a means of self-care with a focus on attention.

According to Cheng et al. (2021), CBT also reduces symptoms of other mental health problems asides from its good effects in treating insomnia. This process strengthens health in various fields and increases resistance to stress in the future [41]. This is in line with Bajaj et al.'s (2020) study in India at the pandemic, which showed that improving sleep reduced depressive symptoms [19].

Another relaxation technique to influence one's cognition and behavior is the Self-instruction Training (SIT) technique. This approach aims to improve an individual's self-control ability through verbal statements that promote, direct, and maintain positive and non-verbal behavior. The method used can be in the form of self-talk, which has higher effectiveness when combined with deep relaxation. The results signified an effect between the combined intervention of SIT and deep breathing relaxation on improving the sleep quality of pregnant women. This indicates that breathing exercises in the CBT process and other types of therapy are beneficial for sleep quality. Another study in the group of pregnant women tested the provision of a Self Instruction Training (SIT) intervention with a combination of deep breathing, indicating that relaxation is useful for reducing tension and anxiety. This is carried out regularly assuming there is a positive effect on insomnia, autonomic function of the heart, depression, anxiety, high blood pressure, and lung disease, balancing body and brain functions of the sympathetic-parasympathetic system. Relaxation has a significant impact on decreasing pulse rate and blood pressure therefore, it makes the body feel calm and overcome sleep disturbances [42].

In addition to specific therapy stated above, psychological support as a form of nonpharmacological therapy is also important to note. Health workers have a higher risk of experiencing psychological problems such as anxiety, depression, and insomnia during the pandemic. This happens because of the tiring work of caring for patients, therefore psychological support is needed for health workers during the pandemic [11].

\section{Insomnia Prevention Efforts During the COVID-19 Pandemic}

Although the treatment of insomnia is important, prevention is better because it is associated with various other diseases. Insomnia is a strong risk factor for various psychiatric and medical morbidities; therefore, focusing on prevention can positively impact public health [41].

The general difference in insomnia cases during the pandemic compared to before its inception is the state of uncertain changes in socioeconomic conditions over a long period. Therefore, various preventive measures need to be conducted from several fields. From the point of view of handling the pandemic, the provision of facilities and resources in handling the pandemic also needs to be a concern. One of the things that have happened in this pandemic is the shortage of Personal Protective Equipment. The availability of PPE in hospitals is a factor that significantly affects mental stress [12]. Hanggoro et al. (2020) stated that the limitations of PPE trigger anxiety for health workers, therefore it is important to provide the right resources for preventive measures [11]. Harmful psychological effects of infectious disease outbreaks persist long after the end of exposure among health workers [9].

Failure to adapt during a pandemic leads to the start of insomnia, therefore it is imperative to recognize triggers and lifestyle modifications to maintain circadian rhythms and prevent its occurrence. It is important to determine the time limit for exposure to information on COVID-19 because when it is above 3 hours or more per day, a higher risk of experiencing symptoms of depression, anxiety, and insomnia is obtained than people with less than 1 hour daily [18]. During a pandemic, excessive internet usage can have negative health impacts, including changes in sleeping habits, diet, decreased physical activity, and disruption in social life. Setting a time limit for internet use and maintaining health through regular exercise are some efforts to maintain a circadian rhythm [21].

Orderly treatment for those diagnosed with insomnia is important to prevent worsening the symptoms. Furthermore, interventions that are specific for any other comorbid diagnoses are required because patients with insomnia sometimes also have comorbid depression or anxiety. Therefore, undergoing treatment as recommended by professionals can prevent worsening the symptoms [34].

Studies on napping also need to be conducted to prevent insomnia-related cases. A 20-30 minute nap can relieve fatigue and sleep, improving reactions and cognitive abilities. When the nap time exceeds 30 minutes, the person becomes more prone to decreased alertness, with weakened cognitive abilities. This is because prolonged naps have the potential to disrupt circadian rhythms and sleep cycles at night. Therefore, the recommended time range is 20-30 minutes [8]. 
Danny Shan Veda et al; Sch J App Med Sci, Jan, 2022; 10(1): 101-110

\section{Conclusion}

In conclusion, the insomnia incidence during the pandemic mostly increased due to sociodemographic factors, which are generally preceded by symptoms of anxiety in response to stressors. Some of the signs and symptoms associated with the pandemic are in the form of difficulty entering the sleep phase, maintaining it, and waking up early. Cognitive Behavior Therapy (CBT) is a common insomnia therapy associated with breathing exercises, which can reduce sleep disturbances. This incidence can be managed and prevented by maintaining circadian rhythms and minimizing risk factors, while complete treatment is the determining factor for recurrence. Complications of other mental health disorders include worsening symptoms of insomnia, anxiety, depression, psychosomatic disorders, and obsessive-compulsive disorder (OCD)

\section{ACKNOWLEDGMENTS}

The authors are grateful to the Medical Faculty, Duta Wacana Christian University, for their support.

\section{REFERENCES}

1. Sadock, B. J., Sadock, V. A., \& Ruiz, P. (2015). Kaplan \& Sadock's Synopsis of Psychiatry : Behavioral Sciences/Clinical Psychiatry.Eleventh edition (11th ed.). Philadelphia: Wolters Kluwer.

2. American Psychiatric Association. (2013). Diagnostic and Statistical Manual of Mental Disorders (5th ed.). Retrieved from ttps://doi.org/10.1176/appi.books.9780890425596

3. Hirshkowitz, M., Whiton, K., Albert, S. M., Alessi, C., Bruni, O., DonCarlos, L., C, R. (2015). National Sleep Foundation's Sleep Time Duration Recommendations: Methodology and Results Summary,. Sleep Health, I(1), 40-43.

4. World Health Organization. (2021). WHO Coronavirus (COVID-19) Dashboard. Accesed on February 27, 2021, from https://covid19.who.int/

5. World Health Organization. (2022). WHO Coronavirus (COVID-19) Dashboard. Accesed on January 5, 2022, from https://covid19.who.int/

6. Haryanti, D. Y. (2020). Insomnia Selama Pandemi COVID-19. Jurnal Ilmiah Kesehatan Sandi Husada, 12(2), 1111-1116.

7. Morin, C. M., \& Carrier, J. (2021). The Acute Effects of The COVID-19 Pandemic on Insomnia and Psychological Symptoms. Sleep Medicine, 77, 346-347.

8. Zhan, Y., Liu, Y., Liu, H., Li, M., Shen, Y., Gui, L., Yu, J. (2020). Factors Associated With Insomnia among Chinese Front-Line Nurses Fighting Against COVID-19 in Wuhan: A CrossSectional Survey. John Wiley \& Sons Ltd $\mid J$ Nurs
Manag | DOI: 10.1111/jonm.13094, 28, 15251535.

9. Martin, A. H., Serrano, J. P., Cambriles, T. D., Arias, E. M., M endez, J. M., Alvarez, M. J., \& S anchez, M. G. (2020). Sleep Characteristics in Health Workers Exposed to The COVID-19 Pandemic. ELSEVIER - Sleep Medicine https://doi.org/10.1016/j.sleep.2020.08.013, 75 (2020), 388-394.

10. Brito-Marques, J. M., FRANCO, C. M., BRITOMARQUES, P. R., MARTINEZ, S. C., \& PRADO, G. F. (2021). Impact of COVID-19 Pandemic on The Sleep Quality of Medical Professionals in Brazil. SciELO Brazil Arq. Neuro-Psiquiatr | https://doi.org/10.1590/0004-282X-anp-2020-0449, 79(2), 149-155.

11. Hanggoro, A., Suwarni, L., Selviana, \& Mawardi. (2020). Dampak Psikologis Pandemi Covid-19 pada Tenaga Kesehatan: A Studi Cross-Sectional di Kota Pontianak. JURNAL KESEHATAN MASYARAKAT INDONESIA, 15(2), 13-18.

12. Bhargava, S., Sarkar, R., \& Kroumpouzos, G. (2020). Mental Distress in Dermatologists during COVID-19 Pandemic:. Wiley Dermatologic Therapy | DOI: 10.1111/dth.14161, 33:e14161.

13. Wang, Y., Zhu, L.-Y., Ma, Y.-F., Bo, H.-X., Deng, H.-B., Cao, J., Wu, X.-J. (2020). Association of Insomnia Disorder With Sociodemographic Factors and Poor Mental Health in COVID-19 Inpatients in China. ELSEVIER - Sleep Medicine https://doi.org/10.1016/j.sleep.2020.06.011, 75(2020), 282-286.

14. Wang, C., Song, W., Hu, X., Yan, S., Zhang, X., Wang, X., \& Chen, W. (2021). Depressive, Anxiety, and Insomnia Symptoms Between Population in Quarantine and General Population during The COVID-19 Pandemic: a CaseControlled Study. BMC Psychiatry https://doi.org/10.1186/s12888-021-03108-2, 21:99.

15. Wang, M., Hu, C., Zhao, Q., Feng, R., Wang, Q., Cai, H., Yang, Y. (2021). Acute Psychological Impact on COVID-19 Patients in Hubei: a Multicenter Observational Study. Translational Psychiatry, 11(133).

16. Zhang, F., Shang, Z., Ma, H., Jia, Y., Sun, L., Guo, X., Liu, W. (2020). Epidemic Area Contact History and Sleep Quality Associated With Posttraumatic Stress Symptoms In The First Phase of COVID-19 Outbreak in China. nature research | Scientific Reports | https://doi.org/10.1038/s41598-02080649-8, 10:22463.

17. Liu, C., Liu, D., Huang, N., Fu, M., Ahmed, J. F., Zhang, Y., Guo, J. (2021). The Combined Impact of Gender and Age on Post-traumatic Stress Symptoms, Depression, and Insomnia During COVID-19 Outbreak in China. Front. Public Health 8:620023. DOI: 10.3389/fpubh.2020.620023, 8 . 
Danny Shan Veda et al; Sch J App Med Sci, Jan, 2022; 10(1): 101-110

18. Mongkhon, P., Ruengorn, C., Awiphan, R., Thavorn, K., Hutton, B., Wongpakaran, N., Nochaiwong, S. (2021). Exposure to COVID-19Related Information and its Association With Mental Health Problems in Thailand: Nationwide, Cross-sectional Survey Study. JOURNAL OF MEDICAL INTERNET RESEARCH, 23(2), e25363.

19. Bajaj, S., Blair, K. S., Schwartz, A., Dobbertin, M., James, R., \& Blair, R. (2020). Worry and Insomnia as Risk Factors for Depression during Initial Stages of COVID-19 Pandemic in India. PLOS ONE | https://doi.org/10.1371/journal.pone.0243527, 15(12), e0243527.

20. Radhakrishnan, A., Govindaraj, R., Sasidharan, A., Ravindra, P., Yadav, R., \& Kutty, B. (2021). People With Dyssomnia Showed Increased Vulnerability to CoVID-19 Pandemic: a Questionnaire-based Study Exploring The Patterns and Predictors of Sleep Quality using The Latent Class Analysis Technique in Indian population. ELSEVIER Sleep Medicine, 79, 29-39.

21. Alfitri, R., \& Widiatrilupi, R. (2020). Dampak Penggunaan Internet terhadap Perkembangan Fisik Remaja pada Masa Pandemi Covid-19 di Kota Malang. Jurnal Formil (Forum Ilmiah) KesMas Respati e-ISSN 2550-0864 p-ISSN 2502-5570, 5(2), 173-184.

22. Firmansyah, Y., Ernawati, Hendsun, H., \& Buntara, I. (2020). Kejadian Insomnia di Masa Pembatasan Sosial Skala Besar (PSBB) Jakarta Akibat Pandemik Covid-19. Hearty - Jurnal Kesehatan Masyarakat, 8(2), 76-83.

23. Tobing, C., \& Wulandari, I. (2021). Tingkat Kecemasan bagi Lansia Yang Memiliki Penyakit Penyerta ditengah Situasi Pandemik Covid-19 di Kecamatan Parongpong, Bandung Barat. Community of Publishing In Nursing (COPING), pISSN 2303-1298, e-ISSN 2715-1980, 9(2), 135-142.

24. Fauziyah, N., \& Aretha, K. (2021). Hubungan Kecemasan, Depresi Dan Stres Dengan Kualitas Tidur Mahasiswa Fakultas Kedokteran Selama Pandemi Covid-19. Herb-Medicine Journal ISSN: 2620-567X, 4(2), 42-50.

25. Zreik, G., Asraf, K., Haimov, I., \& Tikotzky, L. (2020). Maternal Perceptions of Sleep Problems Among Children and Mothers during The Coronavirus Disease 2019 (COVID-19) Pandemic in Israel. Journal of Sleep Research | DOI: 10.1111/jsr.13201, 2021;30:e13201.

26. Al-Ajlouni, Y. A., Park, S. H., Alawa, J., Shamaileh, G., Bawab, A., El-Sadr, W. M., \& Duncan, D. T. (2020). Anxiety and Depressive Symptoms are Associated with Poor Sleep Health during a Period of COVID-19-induced Nationwide Lockdown: a cross-sectional Analysis of Adults in Jordan. BMJ Open | 10:e041995. doi:10.1136/bmjopen-2020-041995.

27. Hetkamp, M., Schweda, A., Bauerle, A., Weismüller, B., Kohler, H., Musche, V., Skoda, E.M. (2020). Sleep Disturbances, Fear, and
Generalized Anxiety During The COVID-19 Shut Down Phase in Germany: Relation to Infection Rates, Deaths, and German Stock Index DA. ELSEVIER - Sleep Medicine https://doi.org/10.1016/j.sleep, 75 (2020), 350-353.

28. Chouchou, F., Augustini, M., Caderby, T., Caron, N., Turpin, N. A., \& Dalleau, G. (2021). The Importance of Sleep and Physical Activity on Wellbeing during COVID-19 Lockdown: Reunion Island as A Case Study. ELSEVIER - Sleep Medicine

https://doi.org/10.1016/j.sleep.2020.09.014, 77, 297-301.

29. Philip, P., Dupuy, L., Morin, C. M., Sevin, E. d., Bioulac, S., Taillard, J., Micoulaud-Franchi, J.-A. (2020). Smartphone-Based Virtual Agents to Help Individuals With Sleep Concerns During COVID19 Confinement: Feasibility Study. JOURNAL OF MEDICAL INTERNET RESEARCH | doi: 10.2196/24268, 22(2).

30. Duran, S., \& Erkin, O. (2021). Psychologic Distress and Sleep Quality Among Adults in Turkey during The COVID-19 Pandemic. ELSEVIER - Progress in Neuropsychopharmacology \& Biological https://doi.org/10.1016/j.pnpbp.2021.110254, 107(110254).

31. Beck, F., Leger, D., Cortaredona, S., Verger, P., Peretti-Watel, P., \& the COCONEL group. (2021). Would We Recover Better Sleep at The End of Covid-19? A Relative Improvement Observed at The Population Level with The End of The Lockdown in France. ELSEVIER - Sleep Medicine, 78, 115-119.

32. Sun, Q., Qin, Q., Basta, M., Chen, B., \& Li, Y. (2021). Psychological Reactions and Insomnia in Adults With Mental Health Disorders during The COVID-19 Outbreak. BMC Psychiatry | https://doi.org/10.1186/s12888-020-03036-7, 21(19).

33. Zou, S., Liu, Z.-H., Yan, X., Wang, H., Li, Y., Xu, X., Xiang, Y.-T. (2020). Prevalence and Correlates of Fatigue and Its Association With Quality of Life Among Clinically Stable Older Psychiatric Patients during The COVID-19 Outbreak: A Crosssectional Study. Globalization and Health | https://doi.org/10.1186/s12992-020-00644-6, 16(119).

34. Li, W., Zhao, L., Yan, X., Zou, S., Wang, H., Li, Y., Xiang, Y.-T. (2021). The Prevalence of Depressive and Anxiety Symptoms and Their Associations with Quality of Life Among Clinically Stable Older Patients with Psychiatric Disorders during The COVID-19 Pandemic. Translational Psychiatry, 11(75).

35. Ubara, A., Sumi, Y., Ito, K., Matsuda, A., Matsuo, M., Miyamoto, T., \& Kadotani, H. (2020). SelfIsolation Due to COVID-19 Is Linked to Small One-Year Changes in Depression, Sleepiness, and Insomnia: Results from a Clinic for Sleep 
Danny Shan Veda et al; Sch J App Med Sci, Jan, 2022; 10(1): 101-110

$\begin{array}{lcccc}\text { Disorders in Shiga } & \text { Prefecture, Japan. Int. J. } \\ \text { Environ. } & \text { Res. } & \text { Public } & \text { Health }\end{array}$ Environ. Res. Public Hed
doi:10.3390/ijerph17238971, 17(8971).

36. Xia, Y., Kou, L., Zhang, G., Han, C., Hu, J., Wen, F., Wang, T. (2020). Investigation on Sleep and Mental Health of Patients With Parkinson's Disease during The Coronavirus Disease 2019 Pandemic. ELSEVIER - Sleep Medicine, 75, 428-433.

37. Kitani-Morii, F., Kasai, T., Horiguchi, G., TeramukaiI, S., Ohmichi, T., Shinomoto, M., Mizuno, T. (2021). Risk Factors for Neuropsychiatric Symptoms in Patients with Parkinson's Disease during COVID-19 Pandemic in Japan. PLOS ONE https://doi.org/10.1371/journal.pone.0245864, 16(1), e0245864.

38. Necho, M., Birkie, M., Gelaye, H., Beyene, A., Belete, A., \& Tsehay, M. (2020). Depression, Anxiety Symptoms, Insomnia, and Coping during The COVID-19 Pandemic Period Among Individuals Living With Disabilities in Ethiopia, 2020.

$$
\text { PLOS }
$$$$
\text { ONE }
$$

https://doi.org/10.1371/journal.pone.0244530, 15(12), e0244530.

39. Cox, R. C., \& Olatunji , B. O. (2021). Linking Insomnia and OCD Symptoms during The
Coronavirus Pandemic: Examination of Prospective Associations. ELSEVIER - Journal of Anxiety Disorders https://doi.org/10.1016/j.janxdis.2020.102341, 77(102341)

40. Weiner, L., Berna, F., Nourry, N., Severac, F., Vidailhet, P., \& Mengin, A. C. (2020). Efficacy of an Online Cognitive Behavioral Therapy Program Developed for Healthcare Workers during The COVID-19 Pandemic: The REduction of STress (REST) Study Protocol for A Randomized Controlled Trial. BMC, 21(870).

41. Cheng, P., Casement, M. D., Kalmbach, D. A., Castelan, A. C., \& Drake, C. L. (2021). Digital Cognitive Behavioral Therapy for Insomnia Promotes Later Health Resilience during The Coronavirus Disease 19 (COVID-19) Pandemic. Sleep Research Society - SLEEPJ, 44(4).

42. Putri, E., \& Margaretta, S. (2020). Penerapan Self Instruction Training Kombinasi Deep Breathing pada Ibu Hamil Untuk Meningkatkan Kualitas Tidur Di Masa Pandemi Covid-19. Jurnal SMART Kebidanan | pISSN: 2301-6213, eISSN: 2503-0388, 7(2), 63-70. 